\title{
PENINGKATAN KEBERHASILAN ASI EKSKLUSIF MELALUI KEGIATAN KELOMPOK PENDUKUNG IBU
}

\author{
Tri Budi Rahayu \\ STIKes Guna Bangsa Yogyakarta
}

\begin{abstract}
Supporting the success of breastfeeding to improve the coverage of exclusive breastfeeding in order to lower the infant mortality rate (IMR) set out in 10 Langkah Menuju Keberhasilan Menyusui (LMKM) policy. One of the steps taken is strive for the establishment of Kelompok Pendukung Ibu (KP-Ibu). This study aims to explain the results of the Kelompok Pendukung Ibu (KP-Ibu) in improving the success of exclusive breastfeeding. Cross-sectional research method with qualitative approach using in-depth interview technique. The results showed there is still one group that the level of attendance $<80 \%$. It is motivated by: 1) There are some KP-Ibu motivator who are less active because the husband follows the work out of town and do not feel confident because it has not had the experience of breastfeeding; 2) Nonavailability of props, tools limited to the manual / guideline; 3) Monitoring and mentoring have not done regularly every 3 months.
\end{abstract}

Keywords: Kelompok Pendukung Ibu, motivator, exclusive breastfeeding

\section{PENDAHULUAN}

Indikator meningkatnya derajat kesehatan dan kesejahteraan masyarakat salah satunya ditandai dengan menurunnya Angka Kematian Bayi (AKB). Pada tahun 2011, Angka Kematian Bayi (AKB) di Indonesia mencapai 34 per $1.000 \mathrm{KH}$. Angka Kematian Bayi (AKB) di Kota Yogyakarta pada tahun 2011 mencapai 10,3 per $1.000 \mathrm{KH}$.

Resiko kematian bayi berusia di bawah 2 bulan meningkat $48 \%$ jika bayi tersebut tidak disusui. Menyusui eksklusif selama 6 bulan dan tetap diberi ASI sampai 11 bulan saja, dengan makanan pendamping ASI pada usia 6 bulan akan menurunkan kematian sebanyak 13\%, karena ASI mengandung zat - zat antibodi yang dapat meningkatkan daya tahan tubuh bayi serta sangat bermanfaat bagi tumbuh kembang yang optimal, baik fisik, mental maupun kecerdasan bayi.

Meskipun regulasi dan program telah ditetapkan oleh pemerintah, namun cakupan pemberian ASI eksklusif masih jauh dari target nasional sebesar $80 \%$. Hasil RISKESDAS tahun 2010 
menunjukkan bahwa cakupan pemberian ASI eksklusif bayi usia 0-5 bulan sebesar $27,2 \%$, sedangkan berdasarkan kelompok umur, bayi usia 5 bulan yang masih mendapat ASI eksklusif hanya sebesar 15,3\%. Berdasarkan data dari Dinas Kesehatan Kota Yogyakarta, cakupan ASI Eksklusif pada tahun 2011 mengalami penurunan dari tahun sebelumnya, yaitu dari $35,51 \%$ menjadi $34,7 \%$.

Sejak tahun 2010, Pemerintah Daerah Kota Yogyakarta telah merencanakan proyek kegiatan pemberdayaan kesehatan masyarakat melalui model Kelompok Pendukung Ibu (KP-Ibu) sebagai hasil kerja sama dengan lembaga kemanusiaan internasional Mercy Corps. Kegiatan tersebut dapat terealisasi pada tahun 2012. Model kegiatan berbasis masyarakat ini menuntut keterlibatan anggota masyarakat demi mencapai keberhasilan tujuan sebagai upaya peningkatan cakupan pemberian ASI eksklusif.

Kelompok Pendukung Ibu (KP-Ibu) merupakan kelompok sebaya yang beranggotakan $8-10$ orang peserta yang terdiri dari ibu hamil, ibu yang memiliki bayi usia $0-6$ bulan, ibu yang memiliki bayi di bawah 2 tahun, maupun peserta yang lain (suami atau wanita yang bukan termasuk ibu hamil maupun ibu menyusui, tetapi ingin mengetahui tentang ASI eksklusif). Kegiatan KP-Ibu dilaksanakan minimal sebulan sekali untuk membahas permasalahan seputar ASI dan menyusui dipandu oleh motivator KP-Ibu.

Meskipun Pemerintah Daerah Kota Yogyakarta dalam hal ini Dinas Kesehatan Kota Yogyakarta telah membuat kebijakan terkait peningkatan cakupan pemberian ASI eksklusif melalui Kelompok Pendukung Ibu (KP-Ibu) yaitu dengan pendekatan tokoh masyarakat, meningkatkan ketrampilan motivator melalui pelatihan, serta menambah sarana prasarana, ternyata pelaksanaan kegiatan KP-Ibu belum berjalan dengan optimal. Hal ini masih terkendala belum semua ibu yang seharusnya menjadi peserta KP-Ibu dapat mengikuti kegiatan Kelompok Pendukung Ibu (KP-Ibu) yang selama ini belum pernah dilakukan evaluasi untuk mengetahui hasil pelaksanaan kegiatan KP-Ibu.

Berdasarkan hasil wawancara dengan 6 motivator KP-Ibu diperoleh data bahwa :

1. Motivator KP-Ibu sudah mendapatkan pelatihan KP-Ibu dan sudah memandu/mendampingi pertemuan rutin KP-Ibu serta melakukan kunjungan rumah ibu bersalin.

2. Tiga motivator KP-Ibu merangkap tugas lain sebagai kader posyandu atau kader PAUD, sehingga mereka merasa kesulitan dalam mengatur waktu untuk pelaksanaan pertemuan rutin KP-Ibu.

3. Ada dua kelompok yang memiliki jumlah peserta melebihi standar (sekitar 15 - 20 orang untuk tiap kelompok).

4. Motivator selalu berkoordinasi dengan kader, RT, RW untuk mendapatkan dukungan, meskipun pihak - pihak tersebut jarang mendatangi pertemuan rutin KP-Ibu.

\section{METODE}

Penelitian ini merupakan penelitian deskriptif dengan rancangan kualitatif untuk memberikan gambaran hasil kegiatan Kelompok Pendukung Ibu (KP$\mathrm{Ibu}$ ). Pengumpulan data dilakukan dengan cara wawancara mendalam (indepth interview) pada 4 orang motivator KP-Ibu yang dipilih dari kelurahan dengan cakupan ASI eksklusif tinggi dan rendah. 
Teknik pengambilan subjek dilakukan secara purposive. Pengolahan dan analisis data dalam penelitian ini menggunakan metode content analysis (analisis isi).

\section{HASIL}

Hasil pelaksanaan kegiatan KP-Ibu dapat dilihat berdasarkan kehadiran peserta pada setiap pertemuan KP-Ibu, yaitu $\geq 80 \%$ dari seluruh jumlah anggota KP-Ibu Hasil penelitian menunjukkan 1 dari 4 kelompok, persentase kehadiran pesertanya belum memenuhi target kehadiran anggota kelompok pada setiap pertemuan,

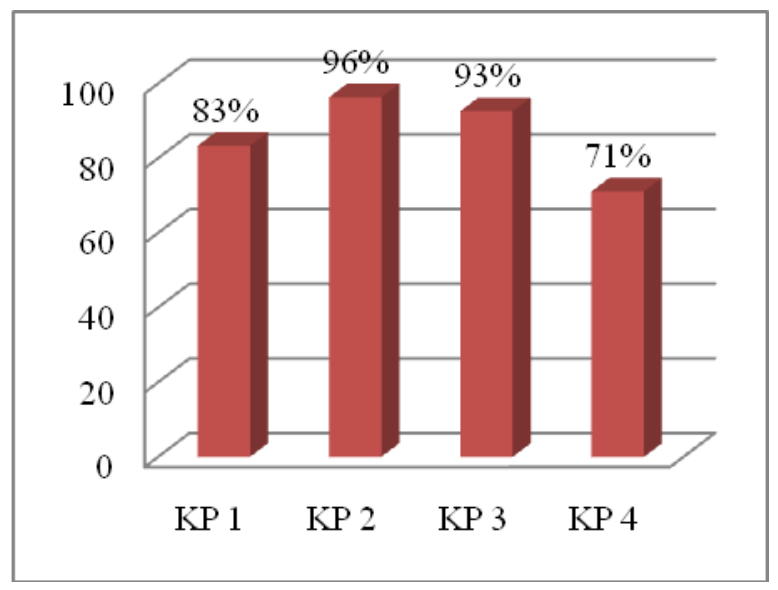

Gambar 1 Persentase Kehadiran Peserta KP-Ibu di Kota Yogyakarta Tahun 2013

\section{PEMBAHASAN, SIMPULAN, SARAN}

Pemerintah Kota Yogyakarta melalui Dinas Kesehatan Kota Yogyakarta (Seksi Gizi dan Kesehatan Keluarga) telah merencanakan proyek kegiatan pemberdayaan masyarakat melalui model Kelompok Pendukung Ibu (KP-Ibu). Model tersebut dapat direalisasikan secara bertahap di 24 kelurahan pada tahun 2012 dan 21 kelurahan pada tahun 2013. Kegiatan ini dilaksanakan dengan tujuan meningkatkan pemberian ASI Eksklusif di Kota Yogyakarta.

Kegiatan ini dimulai dengan mengadakan pelatihan bagi Pembina motivator, yang dalam hal ini diambil dari perwakilan masing - masing kelurahan sejumlah dua orang (tenaga kesehatan puskesmas dan PKK). Selanjutnya, dilakukan sosialisasi KP-Ibu untuk menggalang dukungan dari pihak - pihak yang berpengaruh di masyarakat, sehingga masyarakat bersama Dinas Kesehatan Kota Yogyakarta dan Puskesmas dapat menyusun Rencana Tindak Lanjut dengan agenda dan kegiatan yang jelas. Langkah selanjutnya adalah seleksi motivator. Masing - masing kelurahan memilih 2 - 3 orang untuk dijadikan motivator. Setelah itu, motivator diberikan Pelatihan Motivator Menyusui dengan narasumber dari Pembina Motivator.

Pertemuan KP-Ibu idealnya dilaksanakan 2 minggu - sebulan sekali dengan lama pertemuan 1 jam. Pada kenyataannya, pelaksanaan KP-Ibu diselenggarakan setiap 1 bulan sekali sesuai kesepakatan antara peserta KP-Ibu dengan motivator KP-Ibu.

Berdasarkan hasil wawancara dengan motivator KP-Ibu didapatkan hasil bahwa jumlah motivator di setiap KP-Ibu yaitu $2-3$ orang. Hal ini sesuai dengan teori yang menyatakan bahwa dalam setiap kelompok memiliki $2-3$ motivator, yang diharapkan dapat mengadakan pembagian peran di antara motivator.

Berdasarkan hasil wawancara dengan motivator KP-Ibu, dasar menjadi motivator KP-Ibu berdasarkan usulan kader atau bidan desa. Berikut hasil wawancara dengan motivator : 
Awalnya saya sama teman saya kaget mbak, kok tiba - tiba dihubungi bu Jam, katanya kita dipilih jadi motivator. Bingung juga, harus ngapain, tapi dikasih pengertian sama beliau, mau dilatih dulu.."

IU 3

Dasar pemilihan ini berlawanan dengan kriteria seseorang motivator KPIbu dimana sebaiknya berminat atas keinginan sendiri tanpa paksaan dari pihak lain. Berikut wawancara peneliti dengan pembina KP-Ibu :

“ Iya memang kita yang milih, soalnya kalau menunggu siapa yang mau mengajukan diri, tidak dapat - dapat motivatornya. Kita pilihnya juga yang aktif, masih muda, tinggal disini juga."

IT 3

Hasil wawancara tersebut menunjukkan bahwa meskipun dasar menjadi motivator KP-Ibu atas usulan kader, namun pembina KP-Ibu mempunyai pertimbangan - pertimbangan tertentu dalam memilih motivator. Pertimbangan/alasan tersebut sesuai dengan teori mengenai kriteria motivator KP-Ibu, diantaranya :

1. Berasal dan berdomisili di wilayah yang sama dengan wilayah sasaran aktivitasnya.

2. Sedang menyusui atau memiliki pengalaman menyusui.

Permasalahan yang paling sering dialami oleh motivator adalah kesibukan motivator dan adanya motivator yang mengikuti suami keluar kota, sehingga kurang aktif mengikuti kegiatan Kelompok
Pendukung Ibu (KP-Ibu), seperti yang disampaikan oleh motivator KP-Ibu berikut ini :

"Masalahnya ya itu tadi mbak...kami kewalahan, karena 1 motivator kan jarang sekali datang, jadi yang mendampingi ya gantian."

IU 3

Selain itu, ada motivator KP-Ibu yang merasa kurang percaya diri dalam memandu kegiatan KP-Ibu, seperti yang disampaikan oleh motivator KP-Ibu berikut ini :

"Yang satu memang jarang datang mba. Dulu pernah ditanya juga kenapa jarang ikut kegiatan, trus katanya gak pede, takut kalau salah jawab. Gak pede nya kalau ditanya macem - macem sama peserta. Mungkin karena dia belum pernah menyusui, baru 6 bulan menikah."

IU 4

Berdasarkan hasil wawancara dengan motivator KP-Ibu di atas, dapat diketahui bahwa motivator merasa kurang percaya diri dalam memandu kegiatan KPIbu karena belum mempunyai pengalaman menyusui, sehingga motivator KP-Ibu merasa kesulitan jika ada peserta KP-Ibu yang mengajukan pertanyaan mengenai materi seputar menyusui. Hal ini tidak sesuai dengan teori yang menyatakan bahwa seorang motivator KP-Ibu hendaknya memiliki pengalaman menyusui, sehingga dapat menunjang perannya sebagai motivator KP-Ibu.

Menurut pengamatan peneliti, sarana dalam pelaksanaan kegiatan Kelompok 
Pendukung Ibu (KP-Ibu) berupa buku panduan/pedoman, mainan anak, dan dokumentasi kegiatan KP-Ibu. Akan tetapi, masih ada satu kelompok yang terbatas hanya menggunakan buku panduan sebagai sarananya.

Berdasarkan hasil wawancara dengan motivator KP-Ibu, keterbatasan sarana/prasarana dalam kelompok tersebut disebabkan karena tidak ada pengalokasian khusus bagi pengadaan sarana dan prasarana. Berikut hasil wawancara dengan motivator KP-Ibu mengenai keterbatasan alat yang digunakan dalam kegiatan KP-Ibu :

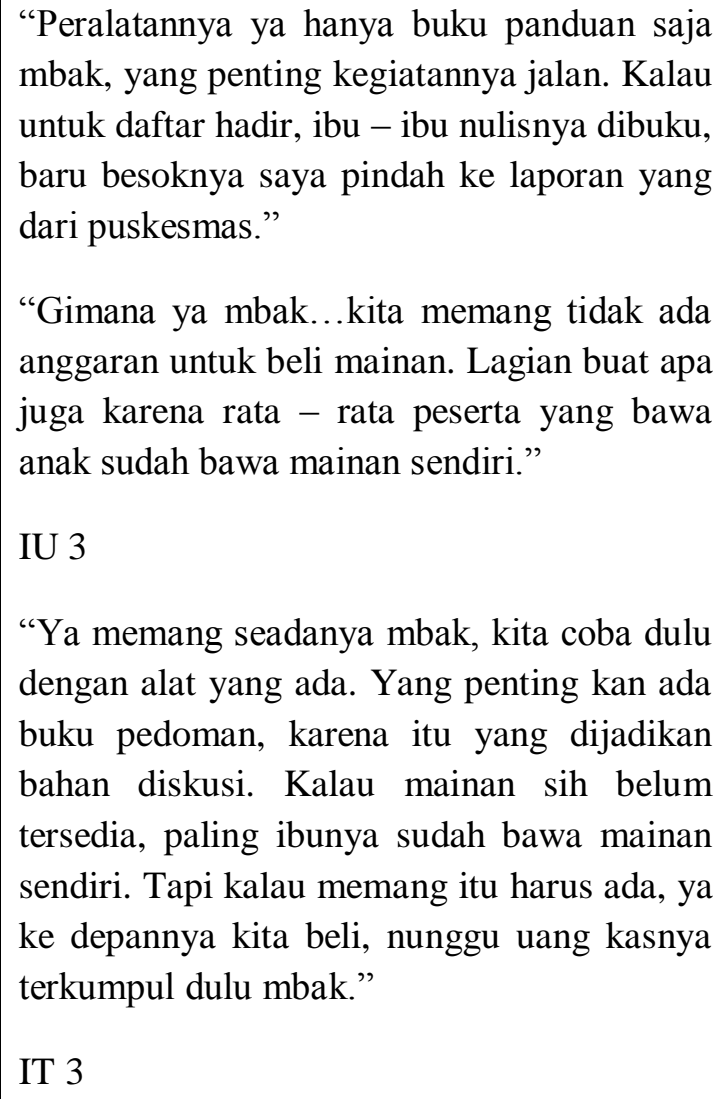
dengan alat yang ada. Yang penting kan ada buku pedoman, karena itu yang dijadikan bahan diskusi. Kalau mainan sih belum tersedia, paling ibunya sudah bawa mainan sendiri. Tapi kalau memang itu harus ada, ya ke depannya kita beli, nunggu uang kasnya terkumpul dulu mbak."

IT 3

yang mempengaruhi hasil kegiatan. Kondisi sarana dan prasarana yang baik antara lain lengkap, modern, berkualitas, dan jumlah cukup akan memberikan kepuasan yang kemudian dapat meningkatkan kinerjanya.

Berdasarkan hasil wawancara, sasaran/peserta KP-Ibu diutamakan ibu hamil dan ibu - ibu yang memiliki bayi usia $0-6$ bulan. Walaupun demikian, kelompok ini terbuka untuk orang - orang lain yang memiliki minat yang sama. Jumlah sasaran/peserta pertemuan KP-Ibu dalam setiap pertemuan adalah antara 8 10 orang, agar setiap orang mendapat kesempatan untuk berbicara dan terjadi diskusi yang aktif. Selain itu, banyaknya peserta akan memperngaruhi lamanya waktu dan luasnya tempat yang diperlukan untuk melaksanakan pertemuan. Akan tetapi, masih ada dua KP-Ibu yang jumlah pesertanya melebihi standar, yaitu $15-18$ orang. Hal tersebut dikarenakan tidak memungkinkan kalau kelompok tersebut dibagi lagi menjadi dua kelompok. Berikut hasil wawancara peneliti dengan motivator KP-Ibu:
Menurut Rahmawati (2007), bahwa ketersediaan sarana dan prasarana penunjang merupakan salah satu factor 
"Mungkin jumlah peserta tempat kita yang paling banyak ya mbak. Idealnya kan memang $8-10$ orang, tapi di tempat kita ada 18 orang. "Lha dulu mau kita jadikan 2 kelompok ribet, takutnya tidak ada yang urus. Tapi kedepannya kita mau rencanakan buat kelompok yang baru lagi, biar lebih efektif."

\section{IU 3}

"Sasaran utamanya adalah ibu hamil dan ibu menyusui yang punya bayi umur $0-6$ bulan. Jumlah di tempat kita ada sekitar 15 orang.... Jumlah ditempat kita memang banyak mbak, karena memang yang hamil dan menyusui jumlahnya segitu. Sebenarnya kalau di RW saya sendiri sudah ada 10 mbak, tapi di RW lain cuma ada 5, kan nanggung kalau dibentuk kelompok sendiri, terlalu sedikit. Jadi sementara kita ikutkan kelompok kita dulu. Besok bulan depan kan kelihatannya nambah, jadi bisa dipecah kelompoknya."

IU 4

Perencanaan merupakan sebuah proses untuk merumuskan masalah masalah yang ada, menentukan kebutuhan sumber daya yang tersedia, menetapkan tujuan kegiatan yang paling cocok, dan menyusun langkah - langkah praktis untuk menyusun tujuan yang telah ditetapkan. Perencanaan merupakan salah satu fungsi manajemen kesehatan yang dilaksanakan dalam upaya mencapai tujuan dari suatu kegiatan.

Pelaksanaan merupakan tahapan yang perlu dilakukan setelah tahap perencanaan selesai dikerjakan. Berdasarkan hasil observasi langsung, pelaksanaan kegiatan KP-Ibu meliputi :
1) Pembukaan

Kegiatan KP-Ibu dibuka oleh motivator dalam suasana yang santai. Motivator KP-Ibu menekankan kembali pentingnya pertemuan/kegiatan tersebut dan menyampaikan materi apa saja yang akan dibahas pada pertemuan saat itu.

2) Membangun keakraban

Motivator KP-Ibu meminta anggota menceritakan pengalamannya baik seputar kehamilan, menyusui maupun hal - hal dalam keluarga, ataupun pengalaman mereka ketika menyebarkan hal - hal menarik yang mereka dapat dari KP-Ibu kepada tetangga/keluarga. Setelah itu, anggota kelompok yang lain memberikan tanggapan terkait pengalaman yang telah diceritakan.

3) Pengumuman dan perayaan

Motivator mengumumkan informasi - informasi yang berguna untuk anggota kelompok. Motivator juga mempersilahkan anggota yang mengetahui suatu informasi penting untuk menyampaikannya dalam kelompok tersebut.

4) Diskusi

Bahan diskusi dalam pertemuan KP-Ibu diutamakan adalah pada isu isu seputar ASI dan menyusui. Meskipun demikian, apabila diskusi berkembang dengan baik maka tidak menutup kemungkinan untuk mencakup isu yang lain yang berkaitan dengan situasi anggota KP-Ibu. Dalam tahapan diskusi, motivator bertugas sebagai fasilitator. Apabila ada pertanyaan dari anggota KP-Ibu, maka akan dibahas pada pertemuan berikutnya.

5) Kesimpulan dan penutup

Motivator menutup pertemuan dengan meminta anggota 
mengemukakan mengenai hal - hal yang telah dipelajari dari pertemuan tersebut, dan mengenai apa yang ingin diperbaiki dari pertemuan tersebut. Motivator meminta kesepakatan dari anggota mengenai tanggal, waktu, tempat, dan topik diskusi untuk pertemuan berikutnya.

Dalam hal pelaksanaan kunjungan rumah bagi ibu yang baru saja melahirkan, dilakukan minimal $1-2$ kali. Saat melakukan kunjungan rumah, motivator KP-Ibu melakukan observasi/pengamatan dan wawancara mendalam dengan ibu dengan menggunakan formulir panduan kunjungan rumah. Hal - hal yang diobservasi/diamati meliputi kondisi ibu dan bayi secara umum, posisi dan perlekatan menyusui, ketersediaan botol, empeng, dan susu formula, serta keadaan rumah secara umum (lingkungan sosial). Sedangkan wawancara mendalam mengenai riwayat persalinan ibu, praktik Inisiasi Menyusu Dini (IMD), dan dukungan fasilitas kesehatan terhadap praktik pemberian ASI. Hal ini sesuai dengan pernyataan informan utama, yaitu :

"Kalau kunjungan rumah, kita usahakan 1-2 kali, syukur bisa lebih. Disitu kita lihat bagaimana keadaan ibu dan bayinya, mendengarkan cerita ibu tentang pengalamannya“"

\section{IU 1}

"Kunjungan rumah disesuaikan dengan waktu kita juga, biasanya 1 kali, dilihat bagaimana ibu menyusuinya. Kita amati secara langsung..."

IU 3
Pengawasan dan pendampingan merupakan fungsi ketiga dari manajemen kesehatan. Pengawasan dan pendampingan sangat diperlukan agar tahapan pelaksanaan dapat dilaksanakan sesuai dengan perencanaan yang telah dibuat dalam pelaksanaan kegiatan Kelompok Pendukung Ibu (KP-Ibu).

Pengawasan dan pendampingan dalam kegiatan Kelompok Pendukung Ibu (KP-Ibu) dilakukan secara berkala dan berkelanjutan kepada motivator KP-Ibu minimal tiga bulan sekali. Pengawasan dan pendampingan yang dilakukan oleh Pembina KP-Ibu ini dimaksudkan agar Pembina KP-Ibu mengetahui kendala kendala yang dihadapi oleh motivator KPIbu sehingga dapat membantu mencari jalan keluar yang tepat.

Pengawasan dan pembinaan belum berjalan secara optimal karena tidak dilakukan secara periodik (minimal 3 bulan sekali) karena kegiatan seringkali dilaksanakan sore hari, dimana pembina KP-Ibu mempunyai kegiatan lain seperti . Berikut pernyataan motivator :

“ Dari puskesmas jarang ikut kegiatan KPIbu. Mungkin karena saya orang Puskesmas juga, jadi kalau laporan ya di Puskesmas"

IU 2

" Dulu awal-awalnya dari Puskesmas datang, tapi sekarang jarang, paling lewat sms saja"

IU 4

Pernyataan tersebut dipertegas oleh pernyataan informan triangulasi :

" Dari Puskesmas memang jarang ikut pertemuan, karena kalau pertemuan kan 
paling sering sore, nah kalau sore dirumah banyak pasien. Jadi saya pantau dari sms atau laporan saja"

IT 4

Supervisi sebaiknya dilakukan pada setiap proses atau kegiatan KP-Ibu karena cara melakukan pengawasan bukan hanya di akhir kegiatan tetapi ketika proses kegiatan berlangsung juga dilakukan supervisi dengan tujuan utama apakah kegiatan yang sedang dilaksanakan telah sesuai rencana atau tidak, atau apakah terjadi penyimpangan yang dapat mengganggu pencapaian tujuan dari kegiatan.

Berbagai alasan dikemukakan oleh peserta KP-Ibu mengenai keikutsertaannya dalam kegiatan KP-Ibu. Berikut hasil wawancara dengan peserta KP-Ibu :

"Alasan kenapa saya mau ikut ya? Yang pertama karena saya suka dengan materi materi yang disampaikan, kemudian suasana pertemuan juga menyenangkan, bertemu sama orang - orang yang sama sama menyusui."

IT 6

"Alasan saya ikut kegiatan, karena penting buat saya, apalagi saya baru punya anak pertama. Pengen lah memberikan yang terbaik untuk anak. Dengan ikut kegiatan kan kita jadi tahu pentingnya ASI eksklusif bagi anak."

\section{IT 8}

Kesadaran peserta KP-Ibu akan pentingnya ASI eksklusif bagi bayinya mendorong mereka untuk mengikuti kegiatan KP-Ibu. Selain itu, persamaan status menyusui pada peserta KP-Ibu juga mendorong mereka untuk ikut aktif dalam kegiatan KP-Ibu.

Dari 4 KP-Ibu hanya $1 \mathrm{KP}$-Ibu yang persentase kehadirannya belum sesiau dengan target keberhasilan KP-Ibu. Berikut hasil wawancara dengan peserta KP-Ibu :

"Kalau untuk alasan ketidakhadiran teman - teman saya, katanya sih karena mereka sibuk, pulangnya malam, jadi tidak sempat datang"

IT 9

Berdasarkan hasil wawancara diatas, dapat diketahui bahwa factor kesibukan peserta menjadi alasan ketidakhadirannya dalam kegiatan KP-Ibu. Factor kesibukan ini dapat juga dimungkinkan karena motivasi yang kurang dari peserta. Banyak pendapat para ahli tentang klasifikasi motivasi, pembagian tersebut dibuat berdasarkan sudut pandang budaya yang digelutinya. Menurut Sartain, motif itu dapat dibedakan menjadi dua golongan yaitu physiological drive (dorongan dorongan yang bersifat fisik) dan social motivies (dorongan - dorongan yang ada hubungannya dengan orang atau manusia yang lain).

Sedangkan jika dikaitkan dengan faktor input dan proses yang telah dibahas, keberhasilan kegiatan KP-Ibu dimungkinkan karena beberapa hal. Dari komponen input, dijelaskan bahwa semua motivator sudah mendapatkan pelatihan tentang menyusui, sehingga tentu saja hal ini akan membantu motivator KP-Ibu dalam menjalankan perannya. Selain itu, motivator memandu kegiatan KP-Ibu dengan metode/cara yang menarik, 
sehingga akan membuat peserta lebih nyaman untuk mengikuti kegiatan KP-Ibu.

\section{DAFTAR PUSTAKA}

Depkes. Strategik Akselerasi Pencapaian Target MDG's 2015. Jakarta; 2008.

Dinkes. Profil Dinas Kesehatan Kota Yogyakarta. Yogyakarta: Dinas Kesehatan Kota Yogyakarta; 2012.

Roesli, U. Inisiasi Menyusu Dini Plus ASI Eksklusif. Jakarta: Pustaka Bunda; 2008.

Kemenkes RI. Riset Kesehatan Dasar. Jakarta: Badan Peneliti dan Pengembangan Kesehatan kemenkes RI; 2010.

Siregar. Pemberian ASI Eksklusif dan Faktor-Faktor yang Mempengaruhinya. Sumatra Utara: FKM Universitas Sumatra Utara; 2004.

Wirawan. Evaluasi Kinerja Sumber Daya Manusia. Jakarta: Salemba Empat; 2009.

Wijono, D. Manajemen Mutu Pelayanan Kesehatan - Teori dan Aplikasi. Surabaya: Airlangga University; 2000.

Azwar, A. Pengantar Administrasi Kesehatan. Jakarta: Binarupa Aksara; 2010.
Supriyanto. Perencanaan dan Evaluasi. Surabaya: FKM-Universitas Airlangga; 2003.

Wijono, D. Manajemen Kepemimpinan dan Organisasi Kesehatan. Surabaya: Airlangga University Press; 1997.

Terry, G.R. Dasar - Dasar Manajemen. Jakarta: Bumi Aksara; 2009.

Siagian, S.P. Fungsi - Fungsi Manajerial. Jakarta: Bumi Aksara; 2007.

Muninjaya, G.A. Manajemen Kesehatan. Jakarta: EGC; 2004.

Sugiyono. Memahami Penelitian Kualitatif. Bandung: Alfabeta; 2009.

Burhan, Bungin. Metodologi Penelitian Kualitatif. Jakarta: Raja Grafindo Prasaja; 2001.

Saryono. Metodologi Penelitian Kualitatif dalam Bidang Kesehatan. Yogyakarta: Salemba Medika; 2010.

Mercy Corps. Buku Panduan Pelatihan Pembina Motivator. 2008. 